14. Pape KE, Wigglesworth JS 1979 Blood supply to the developing brain. In: Haemonhage, Ischaemia and the Perinatal Brain. Spastics International Medical Publications, Lavenham, pp 11-38

15. Nwaesei CG, Allen AC, Vincer MJ, Brown SJ, Stinson DA, Evans JR, Byrne JM 1988 Effect of timing of cerebral ultrasonography on the prediction of later neurodevelopmental outcome in high-risk preterm infants. $J$ Pediatr 112:970-975
16. Graziani LJ, Pasto M, Stanley C, Pidcock F, Desai H, Desai S, Branca P, Goldberg B 1986 Neonatal neurosonographic correlates of cerebral palsy in preterm infants. Pediatrics 78:88-95

17. Costello AM, Hamilton PA, Baudin J, Townsend J, Bradford BC, Stewart AL, Reynolds EOR 1988 Prediction of neurodevelopmental impairment at four years from brain ultrasound appearance of very preterm infants. Dev Med Child Neurol 30:711-722

\title{
Announcement
}

\section{7th Congress of the European Society of Paediatric Radiology}

The European Society of Paediatric Radiology is holding its 27th Congress, May 14-19, 1990, in Munich, Germany. The meeting will have a well-balanced scientific program covering all aspects of pediatric radiology, state-of-the-art techniques in diagnostic and interventional imaging, quality assurance and professional practice. Special programs include a "two days before" industrial visit to Siemens (May 11) and Philips (May 12) with a subsequent city sightseeing tour of Erlangen-Nürnberg and Salzburg, a postgraduate course (May 14 and 15) based on the theme "Rational use of diagnostic imaging in pediatrics," an international symposium on "The status of pediatric radiology in Europe." Accompanying programs include a companion's conference (May 16) on "Bavaria-History, art and modern life" and a post congress tour of the cultural and scenic highlights of Bavaria (May 19 and 20). Deadlines: Papers and posters, December 31, 1989; registration, March 1, 1990. Fees (tentative): Postgraduate course: DM 250; Congress: Nonmembers-regular DM 400/reduced (students and trainees) DM 250; members of the ESPR-regular DM 350/reduced DM 200. Information: Dr. H. Fendel, Univ.-Kinderklinik, Röntgenabteilung, Lindwurmstr. 4, D-8000 München 2, Federal Republic of Germany, Fax. (89) 5160-5388, Tel. (89) 5160-3161. 